\title{
Quantitative Microradiographic Study on the Mineralization and Trabecular Density of Human Vertebral Body
}

\author{
Kozo Sato \\ Department of Orthopedic Surgery (Prof. S. Iino), \\ Tohoku University School of Medicine, Sendai
}

\begin{abstract}
The grade and distribution of mineralization in the postmortal human vertebral body were examined with the technique of quantitative microradiography. The grade of mineralization was indicated by the value of absorption of $\mathrm{x}$-ray through a tested bone, and the trabecular density was shown by the number and width of the trabeculae on the microradiograms. Correlations between the grade of mineralization or trabecular density and ages or pathological conditions were statistically studied.

The grade of mineralization in respective parts of the vertebral body was apt to show almost the same pattern in each case. The trabecular density reached the maximum value in the third decade of life, and thereafter it was lowered by aging, particularly after the fifth decade.

The present study has also revealed that the vertebral body in cases of lung cancer and renal insufficiency has high grade of mineralization, whereas that in liver cirrhosis is lower than normal.
\end{abstract}

In order to know the grade of mineralization of the bone, ash content in bone tissue is usually measured. However, a technique of quantitative microradiography has recently been developed by Engstrom ${ }^{1-4}$ for the determination of the grade of mineralization. This technique has greatly contributed to the studies of bone grafting (Homstrand ${ }^{5}$ ), process of fracture healing (Nilsonne ${ }^{6}$ ) and changes in mineralization of the normal femur by ages (Sissons et $a l .{ }^{7}{ }^{\mathrm{J}} \mathrm{Jowsey}^{8}$ ) and osteoporotic femur (Vose, ${ }^{9}$ Jowsey and Cohne ${ }^{10}$ ).

There are numerous reports about biochemical analysis on homogenized bone in reference to its mineral content. However, only a few works have been done with respect to the quantitative determination of the mineral in bone tissue, particularly in the vertebral body at microscopic level. The author attempted to determine the grade of mineralization and trabecular density of the vertebral body in normal and pathological conditions employing the technique of quantitative microradiography.

\section{Materials and Methods}

The specimens were taken from postmortal vertebral bodies of the lumbar

Received for publication, January 27, 1967. 
portion, mainly the fourth or fifth lumbar vertebra, and prepared as slices approximately $1 \mathrm{~cm}$ thick in a sagittal plane. After dehydration in absolute alcohol, the sliced specimens were embedded in methacrylate resin. Embedded bone was further sliced in $0.2 \mathrm{~mm}$ thickness with an electric saw ${ }^{11}$ and ground finally to approximately $80 \mu$ in thickness, which is suitable for quantitative microradiography.

This thin bone slice was submitted to roentgenography by placing the specimen in contact with a fine-grained $x$-ray film and exposing it to monochromatized $x$-ray according to the method of Engstrom. An x-ray diffraction tube with copper target, a product of Toshiba Electric Company, was used in a condition of $20 \mathrm{kV}$ and $10 \mathrm{~mA}$ with nickel filter of $20 \mu$ in thickness. The wave length of $\mathrm{x}$ ray was so adjusted that more than $80 \%$ of the total emission had a wave length between 1.50 and $1.60 \AA$. This meets practically the requirement of monochromatic $\mathrm{x}$-ray for the present investigation. The nature of $\mathrm{x}$-ray is a type of $\mathrm{CuK} \alpha$ and the wave length at the peak is $1.54 \hat{A}$ as illustrated in Fig. 1. The intensity of
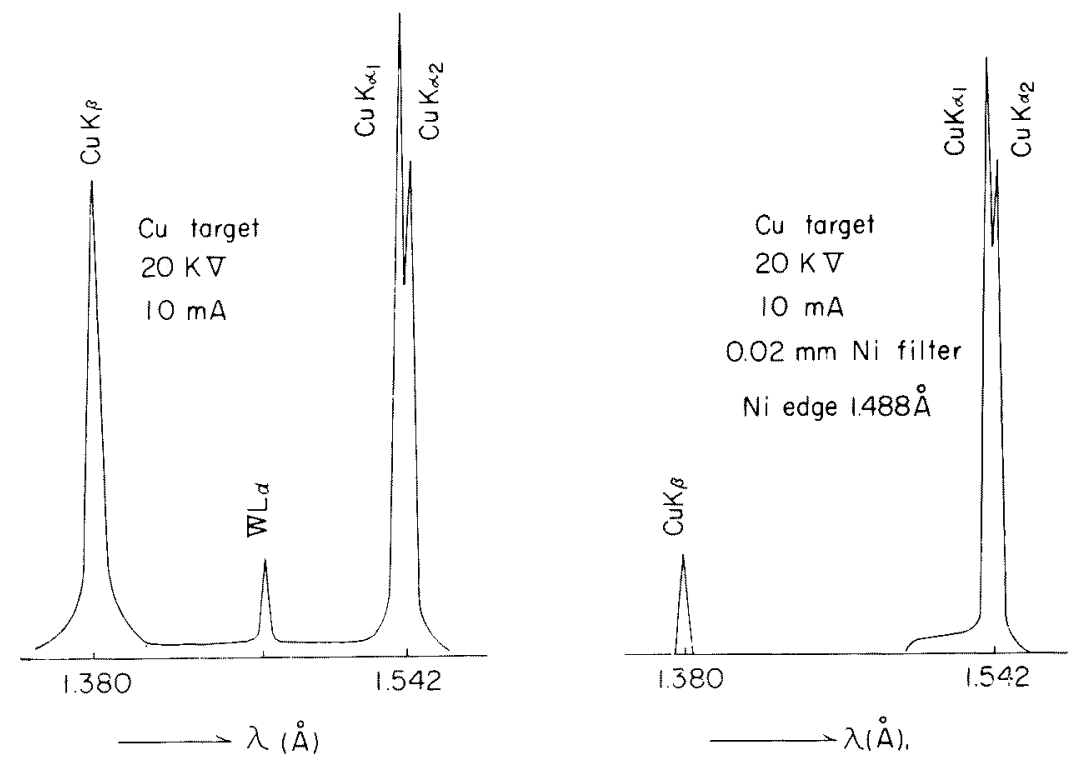

Fig. 1. Distribution of $\mathrm{x}$-ray by wave length emitted from copper target.

irradiation was regulated in such a way that the photographic density of processed $\mathrm{x}$-ray film at the area of the specimen to be tested was between 0.8 and 1.4 . Since the density is too high at the area directly exposed to $x$-ray for photometry, a small piece of copper foil of $30 \mu$ in thickness was used for roentgenograms on the same film. The photographic density of directly exposed area was calculated from the value on the copper foil and the extrapolation of the diagram was done as shown in Fig. 2. The time of exposure was constantly controlled at 70 minutes. The spectroscopic film, type 649-0, a product of Kodak Company, was used in this photography 


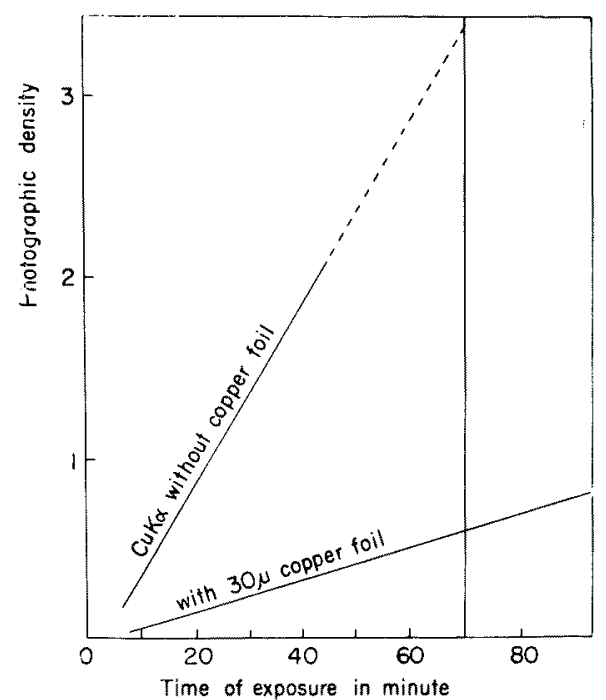

Fig. 2. The photographic density of the film irradiated by copper target $x$-ray tube with and without a copper foil filter and its relation to exposure time under a condition of $20 \mathrm{kV}$ and $10 \mathrm{~mA}$.

and the process of development was done strictly under the same condition all the time. The photometry of the microradiogram was made with a microspectroscopic photometer, a product of Olympus Optical Company, of which pin-hole corresponds to an area of $12.6 \mu$ in diameter on microradiogram. The thickness of the specimen was measured with an electronic micrometer, a product of Anritsu Electric Company.

Linear absorption coefficient (per $\mathrm{cm}$ ) was calculated from the obtained values as described above. This coefficient represents proportionally the grade of mineralization of bone, provided that calcium salt is in the form of hydroxyapatite in the bone.

The trabecular density was determined by measuring the spaces projected on the microradiogram from bone trabeculae in the following way: the number and width of the trabeculae on the horizontal lines, of which four penetrate each vertebral body in equal distances, were measured (Fig. 3). At first, the number of trabeculae across a horizontal line of given length was counted and the width of each trabecula was summed up. When the axis of trabecula does not meet with a given line at rectangle, the width of trabecula was measured in the rectangular direction. The average of trabecular width was then calculated. Total width of trabeculae on a given length is referred to as the density of bone trabecula in medullary bone.

These measurements were done on postmortal vertebral bodies of 137 cases in total. All the specimens were obtained from the vertebrae without macroscopically demonstrable destruction. Thirty-four cases of death due to accident were 


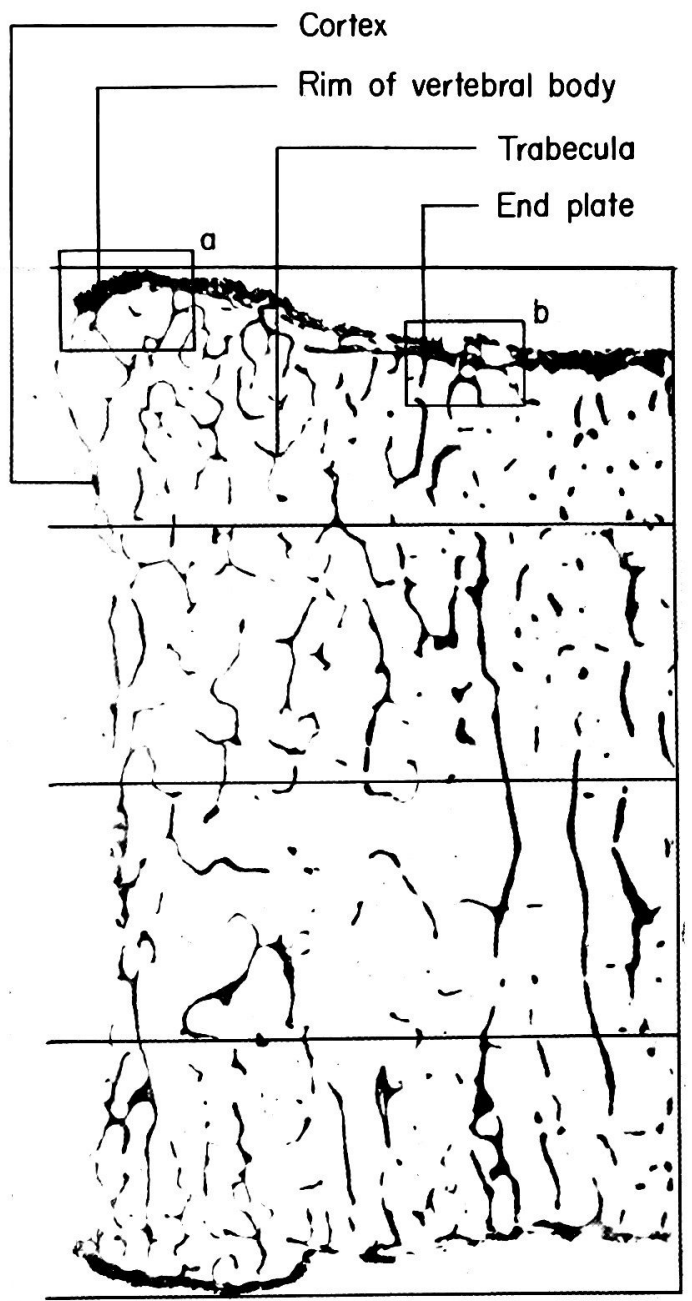

\section{Legends}

Fig. 3A. Microradiogram of a vertebral body in an $80 \mu$ thick vertical section. The number and width of the trabeculae on the horizontal lines crossing the vertebral body were measured. $\times 3$.

Fig. 3B. Microradiograms at four representative areas of vertebral body. $\times \mathbf{4 0}$.

Note: $a$ and $b$ represent the same sites for both figures.

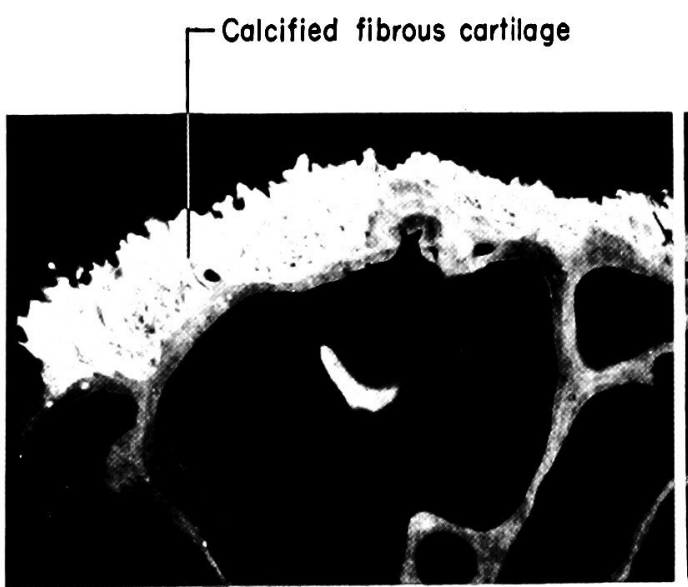

a

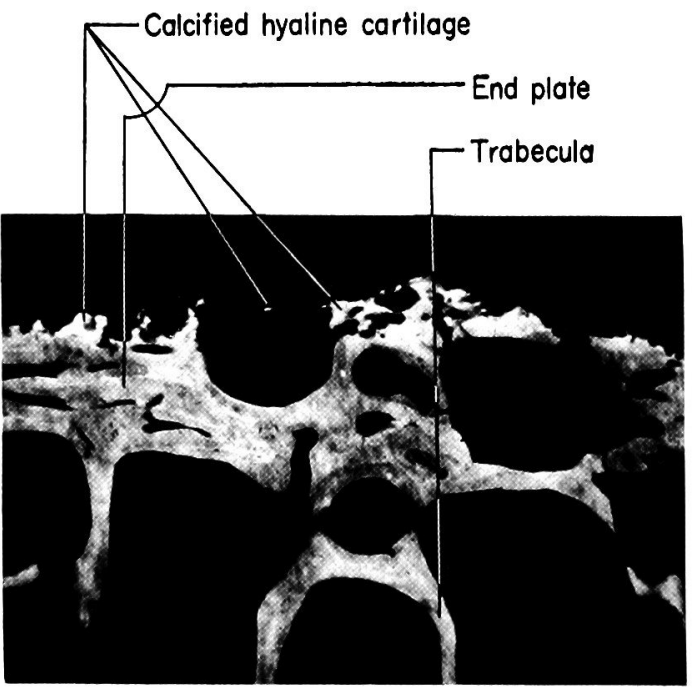

Fig. $3 \mathrm{~B}$ 
treated as controls for statistic study. Others included 45 cases of cancer, 8 of liver cirrhosis, 3 of renal insufficiency, 8 of sarcoma, and 5 of pulmonary tuberculosis. The obtained values were statistically analyzed in reference to each group of diseases and of ages. The number of sample, arithmetic mean and unbiased variance are represented by the letters of $\mathrm{N}, \bar{x}$ and $u^{2}$, respectively, as shown in tables.

\section{Results}

\section{1) Distribution of mineral in the vertebral body}

The difference in the grade of mineralization of vertebral body is surveyed in a number of representative specific areas, namely the rim of the vertebral body, the calcified fibrous cartilage on the rim, the end plate of vertebral body, the calcified hyaline cartilage adjacent to the end plate, the trabecula, and the cortex of the vertebral body. In the area in which the haversian system exists, measurement was made on the interstitial zone (Fig. 3). No significant difference between calcified fibrous cartilage on the rim and calcified hyaline cartilage was found throughout

TABLE 1. The grade of mineralization at the calcified fibrous cartilage on the rim of the vertebral body and the calcified hyaline cartilage adjacent to the end plate

\begin{tabular}{c|c|c|c|c}
\hline & $\begin{array}{c}\text { Decade } \\
\text { of age }\end{array}$ & $\mathrm{N}$ & $\bar{x}$ & $u^{2}$ \\
\hline & 2 & 8 & 143 & 92 \\
& 3 & 6 & 127 & 238 \\
Calcified hyaline & 4 & 7 & 122 & 131 \\
cartilage adjacent & 5 & 15 & 124 & 541 \\
to end plate & 6 & 15 & 132 & 166 \\
& 7 & 11 & 166 & 393 \\
& 8 & 10 & 139 & 379 \\
\hline Calcified fibrous & 2 & 8 & 144 & 155 \\
cartilage on the rim & 3 & 6 & 128 & 601 \\
of vertebral body & 5 & 7 & 125 & 350 \\
& 6 & 15 & 128 & 480 \\
& 7 & 15 & 134 & 205 \\
& 8 & 10 & 126 & 242 \\
& & & 147 & 36
\end{tabular}

$\mathrm{N}$ : Number of samples

$\bar{x}$ : Arithmetic mean

$u_{2}$ : Unbiased variance

the investigation (Table 1). Therefore, they were included in the same category as calcified margin of the vertebral body. The values at the rim of vertebral body were found to be almost the same to that at the end plate. Therefore, these were represented by measurements on the end plate of vertebral body. On the average of all cases the calcified margin of vertebral body was found to show the highest value, and the vertebral end plate and trabeculae at the spongy portion exhibited the second highest rate and then followed by cortical bone. 
2) The change of mineralization rate by age in control group

In the control group the grade of mineralization in the calcified margin of the vertebral body in the fetal age to the first decade was represented by that in the calcified cartilage and the non-remodeled portion of the trabeculae; and in the trabeculae, by that in the remodeled portion of the trabeculae.

The values of mineralization rate at calcified margin of the vertebral body in the second to eighth decades were from 128 to 143 and those in 7 months of fetal age to the first decade were from 170 to 167 , which were obviously larger than the former. The end plate and the trabeculae revealed nearly the same value of bone salt content and they had a similar tendency in changes of mineralization by age.

TABLE 2. The grade of mineralization in four representative areas of vertebral body

\begin{tabular}{|c|c|c|c|c|}
\hline & $\begin{array}{c}\text { Decade } \\
\text { of age }\end{array}$ & $\mathrm{N}$ & $\bar{x}$ & $u^{2}$ \\
\hline & Fetus & 4 & 170 & 7 \\
\hline & 1 & 3 & 167 & 73 \\
\hline & 2 & 2 & 143 & 67 \\
\hline \multirow{6}{*}{$\begin{array}{l}\text { Calcified margin of } \\
\text { vertebral body }\end{array}$} & 3 & 5 & 134 & 73 \\
\hline & 4 & 0 & & \\
\hline & 5 & 4 & 128 & 45 \\
\hline & 6 & 5 & 129 & 55 \\
\hline & 7 & 4 & 141 & 226 \\
\hline & 8 & 5 & 138 & 55 \\
\hline \multirow{9}{*}{$-\cdots \quad \cdots--\cdots$} & Fetus & & & $\cdots$ \\
\hline & $\begin{array}{c}\text { retus } \\
1\end{array}$ & & & \\
\hline & 2 & 2 & 83 & 130 \\
\hline & 3 & 5 & 111 & 105 \\
\hline & 4 & 0 & & \\
\hline & 5 & 4 & 116 & 12 \\
\hline & 6 & 5 & 101 & 31 \\
\hline & 7 & 4 & 113 & 87 \\
\hline & 8 & 3 & 120 & 12 \\
\hline \multirow[t]{9}{*}{$-\cdots$} & Fetus & 4 & 130 & 107 \\
\hline & 1 & 3 & 133 & 83 \\
\hline & 2 & 2 & 93 & 20 \\
\hline & 3 & 4 & 114 & 122 \\
\hline & 4 & 0 & & \\
\hline & 5 & 4 & 114 & 16 \\
\hline & 6 & 5 & 104 & 56 \\
\hline & 7 & 4 & 112 & 19 \\
\hline & 8 & 3 & 123 & 12 \\
\hline \multirow{9}{*}{ Cortex } & Fetus & & & \\
\hline & 1 & & & \\
\hline & 2 & 2 & 73 & 126 \\
\hline & 3 & 3 & 95 & 7 \\
\hline & 4 & 0 & & \\
\hline & 5 & 4 & 98 & 78 \\
\hline & 6 & 5 & 92 & 73 \\
\hline & 7 & 4 & 103 & 117 \\
\hline & 8 & 4 & 101 & 135 \\
\hline
\end{tabular}


In fetus and in the first decade of age, the values at trabeculae were found to be from 130 to 133 , whereas those at trabeculae and vertebral end plate in the 2 nd decade of life were as low as 95 to 83 . It might be due to that the vertebral end plate and remodeled trabeculae are differentiated from the cartilage after the second decade of age and to elevated remodeling activity of bone tissue. After the cease in growth of skeletal system, the values at vertebral end plate and trabeculae were 101 to 120 and 104 to 123 , respectively, without any further significant change through the life. The cortex of the vertebral body, was found to have values from 73 to 103 , which were the lowest values among the three parts of the vertebral body (Table 2). As described above, only a small fluctuation was observed in the grade of mineralization in the four parts of the vertebral body after the third decade of life. These mean values are shown in Table 3.

\begin{tabular}{l} 
TABLE 3. The mean value of the grade of mineralization \\
in four areas of the vertebral body over the \\
third decade of age \\
\hline \begin{tabular}{c|c|c|c} 
\\
Calcified margin & $\mathrm{N}$ & $\bar{x}$ & $u^{2}$ \\
$\quad$ of vertebral body & 21 & 134 & 80 \\
End plate & 21 & 111 & 89 \\
Trabeculae & 20 & 112 & 83 \\
Ccrtex & 20 & 94 & 79
\end{tabular}
\end{tabular}

\section{3) The mineralization of vertebral bodly in pathological conditions}

The vertebral bodies obtained from six patients who died of lung cancer with no metastasis to the spine were found to have obviously larger amount of mineral content in all the portions of vertebral body than in the control. On the other hand, no changes were found in those who died of cancer of the digestive tract or the maxillary bone (Table 4). In each of hypernephroma, malignant chorionepithelioma, cancer of the prostate associated with bile duct involvement, and cancer of the urinary bladder, the values were found to differ from one another, although they were generally higher than in the control (Table 5). In 8 cases of sarcoma, there was no noticeable difference (Table 6). The grade of mineralization of vertebral body in 8 cases of liver cirrhosis was found to be low. On the contrary, in 3 cases of renal insufficiency it was considerably high in all the examined portions of vertebral body except in the calcified margin. No difference was found in cases of pulmonary tuberculosis (Table 7).

\section{4) Trabecular density}

The number and width of trabeculae in medullary portion was surveyed in the cases over the third decade of age as shown in Table 8 . The number of intersecting trabeculae on a unit length showed its maximum as high as 7.4 per $\mathrm{cm}$ 
TABLE 4. The grade of mineralization in the vertebral body in various carcinomas without vertebral metastasis

\begin{tabular}{|c|c|c|c|c|}
\hline & $\begin{array}{c}\text { Parts of } \\
\text { vertebral body }\end{array}$ & $\mathrm{N}$ & $\bar{x}$ & $u^{2}$ \\
\hline \multirow{4}{*}{ Lung cancer } & $\begin{array}{l}\text { Calcified margin } \\
\text { of vertebral body }\end{array}$ & 7 & 150 & 121 \\
\hline & End plate & 7 & 124 & 103 \\
\hline & Trabeculae & 7 & 128 & 88 \\
\hline & Cortex & 7 & 117 & 99 \\
\hline \multirow{4}{*}{$\begin{array}{l}\text { Cancer of the maxillary } \\
\text { bone }\end{array}$} & $\begin{array}{l}\text { Calcified margin } \\
\text { of vertebral body }\end{array}$ & 6 & 130 & 515 \\
\hline & End plate & 6 & 105 & 287 \\
\hline & Trabeoulae & 6 & 105 & 80 \\
\hline & Cortex & 6 & 95 & 326 \\
\hline \multirow{4}{*}{ Stomach cancer } & $\begin{array}{l}\text { Calcified margin } \\
\text { of vertebral body }\end{array}$ & 7 & 134 & 62 \\
\hline & End plate & 9 & 109 & 267 \\
\hline & Trabeculae & 9 & 109 & 198 \\
\hline & Cortex & 9 & 97 & 296 \\
\hline \multirow{4}{*}{$\begin{array}{l}\text { Carcinomas in the di- } \\
\text { gestive canal except } \\
\text { for the stomach }\end{array}$} & $\begin{array}{l}\text { Calcified margin } \\
\text { of vertebral body }\end{array}$ & 7 & 122 & 338 \\
\hline & End plate & 7 & 105 & 381 \\
\hline & Trabeculae & 7 & 107 & 302 \\
\hline & Cortex & 7 & 99 & 369 \\
\hline
\end{tabular}

TABLE 5. High grade of mineralization in cases of malignant tumors

\begin{tabular}{l|c|c|c|c}
\hline & $\begin{array}{c}\text { Calcified margin } \\
\text { of vertebral body }\end{array}$ & End plate & Trabeculae & Cortex \\
\hline $\begin{array}{c}\text { Hypernephroma } \\
\begin{array}{c}\text { Malignant } \\
\text { chorionepithelioma }\end{array}\end{array}$ & 146 & 123 & 129 & 110 \\
$\begin{array}{c}\text { Cancer of the pro- } \\
\text { state associated } \\
\text { with the bile duct }\end{array}$ & 143 & 124 & 127 & 120 \\
$\begin{array}{c}\text { Cancer of the } \\
\text { urinary bladder }\end{array}$ & 140 & 131 & 131 & 109 \\
\end{tabular}

TABLE 6. The grade of mineralization in cases of sarcomas

\begin{tabular}{l|c|c|c}
\hline & $\mathrm{N}$ & $\bar{x}$ & $u^{2}$ \\
\hline Calcified margin & 8 & 131 & 180 \\
of vertebral body & 8 & 107 & 178 \\
End plate & 8 & 107 & 261 \\
Trabeculae & 8 & 107 & 297 \\
Cortex & 7 & 92 &
\end{tabular}


TABLE 7. The grade of mineralization in the vertebral bodies in various disorders

\begin{tabular}{|c|c|c|c|c|}
\hline & $\begin{array}{l}\text { Parts of the } \\
\text { vertebral body }\end{array}$ & $\mathbf{N}$ & $\bar{x}$ & $u^{2}$ \\
\hline \multirow{4}{*}{ Liver cirrhosis } & $\begin{array}{l}\text { Calcified margin } \\
\text { of vertebral body }\end{array}$ & 8 & 111 & 26 \\
\hline & End plate & 8 & 89 & 86 \\
\hline & Trabeculae & 7 & 93 & 66 \\
\hline & Cortex & 8 & 82 & 157 \\
\hline \multirow{4}{*}{ Renal insufficiency } & $\begin{array}{l}\text { Calcified margin } \\
\text { of vertebral body }\end{array}$ & 3 & 143 & 163 \\
\hline & End plate & 3 & 131 & 31 \\
\hline & Trabeculae & 3 & 131 & 18 \\
\hline & Cortex & 2 & 116 & 8 \\
\hline \multirow{4}{*}{$\begin{array}{l}\text { Pulmonary } \\
\text { tuberculosis }\end{array}$} & $\begin{array}{l}\text { Calcified margin } \\
\text { of vertebral body }\end{array}$ & 4 & 137 & 148 \\
\hline & End plate & 4 & 112 & 59 \\
\hline & Trabeculae & 4 & 105 & 77 \\
\hline & Cortex & 4 & 101 & 82 \\
\hline
\end{tabular}

TABLE 8. The number and width of trabeculae in reference to age

\begin{tabular}{|c|c|c|c|c|c|c|c|}
\hline \multirow{2}{*}{$\begin{array}{l}\text { Decade } \\
\text { of } \\
\text { age }\end{array}$} & \multirow[t]{2}{*}{$N$} & \multicolumn{2}{|c|}{$\begin{array}{c}\text { Number of } \\
\text { trabecula }\left(\mathrm{cm}^{-1}\right)\end{array}$} & \multicolumn{2}{|c|}{$\begin{array}{l}\text { Summation of the } \\
\text { width of } \\
\text { trabeculae }(\mathrm{mm} / \mathrm{cm})\end{array}$} & \multicolumn{2}{|c|}{$\begin{array}{l}\text { Average width of } \\
\text { trabeculae }(\mathrm{mm})\end{array}$} \\
\hline & & $\bar{x}$ & $u^{2}$ & $\bar{x}$ & $u^{2}$ & $\bar{x}$ & $u^{2}$ \\
\hline 3 & 15 & 7.4 & 29.3 & 1.05 & 7.12 & 0.13 & 5.11 \\
\hline 4 & 15 & 7.0 & 17.0 & 0.79 & 5.56 & 0.11 & 5.99 \\
\hline 5 & 21 & 6.5 & 33.1 & 0.70 & 5.95 & 0.11 & 8.77 \\
\hline 6 & 21 & 5.0 & 28.5 & 0.55 & 3.38 & 0.11 & 3.39 \\
\hline 7 & 24 & 4.8 & 17.4 & 0.53 & 2.97 & 0.11 & 3.26 \\
\hline 8 & 14 & 4.2 & 26.1 & 0.49 & 7.30 & 0.10 & 7.53 \\
\hline
\end{tabular}

in the third decade, then it gradually decreased with advancing age to as low as 4.2 in the eighth decade of life. In this process of decrease, the diminution was remarkable from the fifth to sixth decade. The width of each trabecular per $\mathrm{cm}$ of length in vertebral body was measured and summed up; it was $1.05 \mathrm{~mm} / \mathrm{cm}$ in the third decade, and $0.49 \mathrm{~mm} / \mathrm{cm}$ in the eighth decade, with a notable lowering in its value between the fifth and sixth decades. The pattern of decrease in trabecular width by age resembled that in the trabecular number by age. The average width of the trabeculae was $0.13 \mathrm{~mm}$ in the third decade, without any notable change thereafter.

The number and width of the trabeculae showed on the whole similar values in both sexes, although the females over the seventh decade were apt to have considerably low values. There was no difference in the average width of the 
TABLE 9. The number and width of trabeculae against sex difference

\begin{tabular}{|c|c|c|c|c|c|c|c|c|}
\hline \multirow{2}{*}{$\begin{array}{l}\text { Decade } \\
\text { of } \\
\text { age }\end{array}$} & \multirow[t]{2}{*}{ Sex } & \multirow[t]{2}{*}{$\mathrm{N}$} & \multicolumn{2}{|c|}{$\begin{array}{c}\text { Number of } \\
\text { trabeculae }\left(\mathrm{cm}^{-1}\right)\end{array}$} & \multicolumn{2}{|c|}{$\begin{array}{l}\text { Summation of the } \\
\text { width of } \\
\text { trabeculae }(\mathrm{mm} / \mathrm{cm})\end{array}$} & \multicolumn{2}{|c|}{$\begin{array}{l}\text { Average of width } \\
\text { trabeculae }(\mathrm{mm})\end{array}$} \\
\hline & & & $\bar{x}$ & $u^{2}$ & $\bar{x}$ & $u^{2}$ & $\bar{x}$ & $u^{2}$ \\
\hline 3 & $\$$ & $\begin{array}{r}14 \\
3\end{array}$ & $\begin{array}{l}7.4 \\
7.4\end{array}$ & $\begin{array}{l}26.8 \\
20.1\end{array}$ & $\begin{array}{l}1.08 \\
0.93\end{array}$ & $\begin{array}{l}7.24 \\
7.47\end{array}$ & $\begin{array}{l}0.13 \\
0.13\end{array}$ & $\begin{array}{l}6.07 \\
0.61\end{array}$ \\
\hline 1 & $\begin{array}{l}\hat{\partial} \\
\text { q }\end{array}$ & $\begin{array}{l}6 \\
9\end{array}$ & $\begin{array}{l}7.5 \\
6.6\end{array}$ & $\begin{array}{l}16.2 \\
1.77\end{array}$ & $\begin{array}{l}0.78 \\
0.79\end{array}$ & $\begin{array}{l}7.87 \\
4.65\end{array}$ & $\begin{array}{l}0.11 \\
0.11\end{array}$ & $\begin{array}{l}7.10 \\
5.81\end{array}$ \\
\hline 5 & $\begin{array}{l}3 \\
8\end{array}$ & $\begin{array}{r}16 \\
5\end{array}$ & $\begin{array}{l}6.5 \\
6.3\end{array}$ & $\begin{array}{l}30.6 \\
29.0\end{array}$ & $\begin{array}{l}0.70 \\
0.71\end{array}$ & $\begin{array}{l}5.66 \\
4.62\end{array}$ & $\begin{array}{l}0.11 \\
0.11\end{array}$ & $\begin{array}{r}10.81 \\
2.96\end{array}$ \\
\hline 3 & $\begin{array}{l}\delta \\
q\end{array}$ & $\begin{array}{r}14 \\
7\end{array}$ & $\begin{array}{l}5.0 \\
5.1\end{array}$ & $\begin{array}{l}30.8 \\
28.0\end{array}$ & $\begin{array}{l}0.55 \\
0.56\end{array}$ & $\begin{array}{l}3.72 \\
3.73\end{array}$ & $\begin{array}{l}0.11 \\
0.11\end{array}$ & $\begin{array}{l}2.93 \\
4.32\end{array}$ \\
\hline 7 & $\begin{array}{l}1 \\
8\end{array}$ & $\begin{array}{r}19 \\
5\end{array}$ & $\begin{array}{l}4.9 \\
4.1\end{array}$ & $\begin{array}{l}16.7 \\
17.7\end{array}$ & $\begin{array}{l}0.56 \\
0.42\end{array}$ & $\begin{array}{l}2.92 \\
2.17\end{array}$ & $\begin{array}{l}0.11 \\
0.11\end{array}$ & $\begin{array}{l}3.08 \\
1.79\end{array}$ \\
\hline 3 & $\begin{array}{l}8 \\
8\end{array}$ & $\begin{array}{r}10 \\
4\end{array}$ & $\begin{array}{l}4.7 \\
3.1\end{array}$ & $\begin{array}{l}16.5 \\
41.3\end{array}$ & $\begin{array}{l}0.57 \\
0.37\end{array}$ & $\begin{array}{l}7.37 \\
0.51\end{array}$ & $\begin{array}{l}0.11 \\
0.09\end{array}$ & $\begin{array}{l}9.52 \\
0.12\end{array}$ \\
\hline
\end{tabular}

trabeculae between both sexes (Table 9).

\section{Discussion}

Quantitative measurement of calcium in bone tissue has been done previously by means of biochemical techniques, in which calcium salt is measured on a certain weight or volume of bone pieces. It is impossible, however, to know the quantitative distribution of minerals in direct relation to the histological findings of bone tissue by this method. Since quantitative microradiography was applied to the study of bone structure by Engström ${ }^{1}$ in 1946 , the modes of mineralization have been investigated in different conditions of the bone by many investigators.

In this method, the quantity of bone mineral is expressed by the value of thickness of standardized material or by the value of absorption coefficient derived from the degrees of blackness of the processed film after its exposure to roentgen ray through a tested bone. The calcium salt in bone tissue is thought to be hydroxyapatite and this is the main substance related to absorption of roentgen ray in bone tissue. From the values of linear absorption coefficient obtained from the present experiments and the mass absorption coefficient of hydroxyapatite, it is possible to know the density of hydroxyapatite in bone tissue in situ, consequently the quantity of $\mathrm{Ca}$ deposition in the bone at different areas can be estimated. According to Engstrom ${ }^{4}$ the mass absorption coefficient of hydroxyapatite is given by $\mu / \rho=83 \cdot \mathrm{g}^{-1} \cdot \mathrm{cm}^{2}$, where $\mu$ is the absorption coefficient per $\mathrm{cm}$ and $\rho$ is the density in $\mathrm{g} \cdot \mathrm{cm}^{-3}$. The values obtained from the normal vertebral bodies are shown in Table 10 . These are found to be consistent with those by Sissons et al. ${ }^{7}$ who employed the methods of Alwedge. The density of hydroxyapatite in the vertebral bodies at embryonic stage and until 9 months of life was found to be 2.04 , a value very close to 2.0 of pure hydroxyapatite. It 
TABLE 10. The linear absorption coefficient of vertebral bodies over the 3 rd decade and its relation to the quantity of hydroxyapatite and calcium

\begin{tabular}{l|c|c|c}
\hline & $\begin{array}{c}\text { Linear absorption } \\
\text { coefficient } \mu\left(\mathrm{cm}^{-1}\right)\end{array}$ & $\begin{array}{c}\text { Amount of hydroxy } \\
\text { apatite }\left(\mathrm{g} / \mathrm{cm}^{3}\right)\end{array}$ & $\begin{array}{c}\text { Weight of } \\
\text { calcium }(\mathrm{g} / \mathrm{cm})\end{array}$ \\
\hline $\begin{array}{c}\text { Calcified margin } \\
\text { of vertebral body }\end{array}$ & 134 & 1.61 & 0.64 \\
End plate & 111 & 1.34 & 0.54 \\
Trabeculae & 112 & 1.35 & 0.54 \\
Cortex & 94 & 1.13 & 0.45
\end{tabular}

is assumed from this finding that the maximum density of bone salt is found in the area where bone salt deposition takes place in early ages, provided that the bone salt in early ages is hydroxyapatite. The determination of composition of bone salt in such an early age is beyond the scope of the present observation.

Sissons et al. ${ }^{7}$ showed on cross section specimens of the femur that the haversian canals became widened and the ratio of highly calcified osteon was increased with the advance of age. On the other hand, Jowsey et al. ${ }^{10}$ reported a lower ratio of calcified osteons in the femur with osteoporosis as well as Bohr, ${ }^{12}$ who obtained similar results from pieces of iliac bone in osteoporosis.

It was found in the present investigation that there was always a definite order in the distribution of bone salt in respective portions of vertebral body. The grade of mineralization was shown in the following order from high to low grade: The calcified margin of vertebral body, end plate of vertebral body or bone trabeculae in the spongy marrow, and cortical bone. The calcified marginal area is presumably not remodeled. Accordingly, its bone salt content was found to become decreased gradually with the advance of age, whereas the bone salt content in bone trabeculae, end plate of vertebrae and cortex in the second decade of age were found to be remarkably decreased. This would be interpreted to be due to an active remodeling of skeletal tissue in this decade. After the third decade of age, the bone salt content did not change significantly. The dynamic strongness of the bone, which is larger in the third decade than in any other age of life, is not necessarily due to a large bone salt content, and is thought to be more closely related to the mode of arrangement of bone trabeculae and their density in skeletal tissue.

The summation of the widths of respective bone trabeculae on a unit length has a parallel relation to either the number or the average width of bone trabeculae, consequently to the trabecular density (Table 11). It was found in the present investigation that the density of bone trabeculae had its maximum in the third decade of life. Then it became decreased with advancing ages, particularly in the fifth and sixth decades of life. As mentioned above, the dynamic strength of bone is largest in the third decade where the density of trabecula has its maximum value. The reports of Bauer ${ }^{13}$ and Tatematu ${ }^{14}$ that the incidence of pathological fracture 
TABLE 11. The number of trabeculae, summation of their widths and average width of trabecula

\begin{tabular}{c|c|c|c|c}
\hline \multicolumn{1}{c|}{} & \multicolumn{3}{|c}{ Correlation } \\
$\begin{array}{c}\text { Decade } \\
\text { of } \\
\text { age }\end{array}$ & $\mathrm{N}$ & $\begin{array}{c}\text { Number and summation } \\
\text { of widths of trabeculae }\end{array}$ & $\begin{array}{c}\text { Summation of width of } \\
\text { trabeculae and average } \\
\text { trabecular width }\end{array}$ & $\begin{array}{c}\text { Number and } \\
\text { average width } \\
\text { of trabeculae }\end{array}$ \\
\hline 3 & 15 & 0.55 & 0.59 & $(-)$ \\
4 & 15 & $(-)$ & 0.83 & $(-)$ \\
5 & 21 & 0.49 & 0.44 & $(-)$ \\
6 & 21 & 0.91 & $(-)$ & $(-)$ \\
7 & 24 & 0.75 & 0.46 & $(-)$ \\
8 & 14 & 0.31 & 0.59 & $(-)$
\end{tabular}

$(-)$ : No significant relation.

is most frequent in the fifth decade may be explained by the result of the present study. The condition of the bone in this age characterized by decrease in the trabecular density and predisposing pathological fractures is to be designated as osteoporosis.

The vertebral bodies obtained from patients who died of lung cancer, hypernephroma, prostatic cancer and cancer of urinary bladder without metastasis to the spines showed evidently high mineralization. It is widely known that cancers of breast, lung and prostate or hypernephroma very frequently metastasize to skeletal tissue. As one of the causes ${ }^{15-19}$ contributing to this process, hypercalcemia has been generally taken into consideration. ${ }^{2,5,6,13,16}$ However, Ehrlich ${ }^{20}$ observed hypocalcemia, hypoparathyroidism or elevated rate of bone formation in a case of prostatic cancer accompanied by osteoplastic metastasis to the bone tissue. In our four cases of cancer in which serum Ca was examined, no hypercalcemia was found, whereas hypocalcemia was noted in a case of urinary bladder cancer.

Of four cases of renal insufficiency in the present series of observation, three cases apparently showed high $\mathrm{Ca}$ content and the other showed, on the contrary, a low level. The serum Ca level was apt to be rather low in the cases of high Ca content in the bone. The tendency of low calcium level in serum should be taken in consideration for high $\mathrm{Ca}$ deposition in the bone.

Atkinson (1956) ${ }^{21}$ observed osteoporosis or osteomalacia in 7 cases out of 25 of hepatic and post-hepatic jaundice. In the present investigation, all the 8 cases of liver cirrhosis showed remarkably low grades of bone salt content. Atkinson also pointed out that the change in skeletal tissue was noticed within 6 months after the beginning of hepatic jaundice, but it appeared evident only after more than 3 years in the cases of post-hepatic jaundice. In the present investigation, similarly, the cases of post-hepatic jaundice had not any abnormality in mineralization of vertebral bodies 4 months in one case, and one year and 8 months in another case after the onset of the disease. Presumably, the decrease in bone salt content is due to vitamin $\mathrm{D}$ deficiency induced by functional disturbances of liver 
parenchym as pointed out by Atkinson, or insufficiency in the formation of ground substance in the bone. The application of quantitative microradiography in the present investigation for determining the grade of mineralization in the bone must be further extended to the bone in pathological conditions and for a diagnostic device combined with biochemical study with radioisotope and with the study of dynamic hardness of bone with an osteosclerometer.

\section{References}

1) Engström, A. Quantitative miero- and histochemical elementary analysis by roentgen absorption spectrography. Acta radiol., 1946, Suppl. 63.

2) Engström, A. The detection of small differences in cellular mass by historadiography and a new equipment for microradiography. Exp. Cell Res., Suppl. 1955, 3, 117-123.

3) Engström, A., Langergren C. \& Lundberg, B. Determination of strontium and calcium in bone by X-ray absorptiometry. Exp. Cell Res., 1957, 12, 592-598.

4) Engström, A. Bone and Radiostrontium. John Willey \& Sones, Inc. N.Y., 1958.

5) Holmstrand, K. Biophysical investigations of bone transplants and bone implants. Acta orthop. scand., 1957, Suppl. 26.

6) Nilsonne, U. Biophysical investigations of the mineral phase in healing fractures. Acta orthop. scand,, 1959, Suppl. 37.

7) Sissons, H.A., Jowsey, J. \& Stewart, L. Quantitative microradiography on bone tissue. X-ray microscopy and X-ray microanalysis, Elsevier Publ. Co., Amsterdam, 1961, pp. 199-215.

8) Jowsey, J. Age changes in human bone. Clin. Orthop., 1960, 17, 210-218.

9) Vose, G.P. Quantitative microradiography of osteoporotic compact bone. Clin. Orthop., 1962, 24, 206-212.

10) Jowsey, J. \& Cohne, J.G. Clinical and experimental osteoporosis. Bone and Tooth, Pergamon Press, London, 1964, pp. 35-47.

11) Suzuki, M. Studies on new autoslicer for calcified hard tissue. Tohoku Igaku Zassi (Jap.), 1963, 67, 691-695.

12) Bohr, H. Chemical analysis and microradiographic investigations on bone biopsies from cases of osteoporosis and osteomalacia as compared with normal. Part II. Microradiographic studies in normal, osteoporotic and osteomalacic bone. Bone and Tooth, Pergamon Press, London, 1964, pp. 405-409.

13) Bauer, G.C.H. Epidemiology of fracture in aged persons. Clin. Orthop., 1960, 17, 219-225.

14) Tatematu, M. Osteoporosis. Nippon Seikeigekagakkai Zasshi (Jap.), 1964, 38, 441456.

15) Baker, W.H. Abnormalities in calcium metabolism in malignancy; Effects of hormone therapy. Amer. J. Med., 1956, 21, 714-720.

16) Castleman, B. \& MoNeely, B.U. Case records of the Massachusetts General Hospital; Case 21-1964. New Eng. J. Med., 1964, 270, 898-906.

17) Castleman, B. Case records of the Massachusetts General Hospita]; Case 29-1964. New Eng. J. Med., 1964, 270, 1302-1309.

18) Horton, K. \& Olson, K.B. Hypercalcemia associated with cancer of the breast and other organs. Bone and Tooth, Pergamon Press, London, 1964, pp. 207-216.

19) Myers, W.P.L. Hypercalcemia in neoplastic disease. Arch. Surg., 1960, 80, 308-318.

20) Ehrlich, M., Goldstein, M. \& Heinemann, H.O. Hypocalcemia, hypoparathyroidism and osteoblastic metastasis. Metabolism, 1963, 12, 516-526.

21) Atkinson, M., Nordin, B.E.C. \& Sherlock, S. Malabsorption and bone disease in prolonged obstructive jaundice. Quart. J. Med., 1956, 25, 299-312. 